\title{
HUBUNGAN ASUPAN ENERGI, CAIRAN DAN LAMA RAWAT INAP DENGAN PERUBAHAN BERAT BADAN PASIEN BALITA DIARE DI RSUD dr. DORIS SYLVANUS PALANGKA RAYA
}

\author{
Correlation between Energy Intake, Fluid Intake, Length of Stay and Body \\ Weight Changes of Pediatric Patients with Diarrhea at RSUD dr. Doris \\ Sylvanus Palangka Raya
}

Fretika Utami Dewi ${ }^{1}$, Hermawati ${ }^{2}$

${ }^{1}$ Prodi DIV Gizi Poltekkes Kemenkes Palangka Raya, ${ }^{2}$ Mahasiswa Prodi DIV Gizi Alamat korespondensi : dewiutami_f@yahoo.co.id

\begin{abstract}
Inadequate energy intake, non-infectious diseases, special diets and long days of treatment are factors that influence the occurrence of malnutrition in hospitals. This study aims to determine correlation between energy intake, fluid intake, length of stay and body weight changes of toodlers with diarrhea at RSUD dr. Doris Sylvanus Palangka Raya. It employed a cross-sectional study design with purposive sampling method. Energy and fluid intake of 30 diarrhea toddlers were obtained using 24-hour food recall form. Their body weight data were recorded before and after treatment. Data were analyzed using simple linear regression and Spearman tests. Results: most of respondents were 2 years old (36.7\%), consumed soft food diet (86.7\%), get parenteral nutrition KA-EN 3B (66.7\%), severe energy deficit (40\%), excessive fluid intake (83.3\%) and length of stay $<5$ days (73.3\%). As many as 21 toodlers experienced weight gain $(70 \%)$. Simple linear regression test of energy intake and body weight changes showed a $p$ value of 0.5 . Spearman test of fluid intake and length of hospitalization toward body weight changes showed $p$ value of 0.049 and 0.820 , respectively. Conclusion: There was no correlation between energy intake, length of stay and body weight changes but there was a positive relationship between fluid intake and body weight changes.
\end{abstract}

Key words : Changes in Body Weight, Energy Intake, Fluid Intake, Length of Stay.

\begin{abstract}
ABSTRAK
Asupan energi inadekuat, penyakit non infeksi, diet khusus dan lama hari perawatan merupakan faktor yang mempengaruhi terjadinya malnutrisi di rumah sakit. Tujuan penelitian adalah untuk mengetahui hubungan asupan energi, cairan dan lama hari rawat inap dengan perubahan berat badan pada pasien balita diare di RSUD dr. Doris Sylvanus Palangka Raya. Rancangan penelitian cross sectional yang bersifat deskriptif analitik. Jumlah sampel sebanyak 30 orang balita diare yang diambil secara purposive sampling. Data asupan energy dan cairan diperoleh dengan food recall 24 jam selama pasien dirawat. Data berat badan diperoleh dengan menimbang sampel saat awal dan akhir perawatan. Data dianalisis menggunakan uji regresi linear sederhana dan uji spearman. Hasil penelitian : sampel terbanyak berusia 2 tahun (36,7\%), bentuk makanan nasi lunak (86,7\%), nutrisi parenteral KA-EN 3B $(66,7 \%)$, asupan energy $40 \%$ defisit berat, asupan cairan $83,3 \%$ diatas kebutuhan dan lama lama rawat inap < 5 hari $(73,3 \%)$. Sampel yang mengalami kenaikan berat badan sebanyak 21 orang $(70 \%)$. Uji regresi linear sederhana asupan energi dengan perubahan berat badan $\mathrm{p}$ value 0,5 , uji spearman asupan cairan dengan perubahan berat badan $\mathrm{p}$ value 0,049 , lama hari rawat inap dengan perubahan berat badan $\mathrm{p}$ value 0,820 . Kesimpulan: Tidak ada hubungan antara asupan energi, lama hari rawat inap dengan perubahan berat badan, ada hubungan asupan cairan dengan perubahan berat badan.
\end{abstract}

Kata Kunci : Perubahan Berat Badan, Asupan Energi, Asupan Cairan, Lama Hari Rawat Inap. 


\section{PENDAHULUAN}

Penyakit diare atau gastroenteritis adalah penyakit multifaktorial, yang dapat disebabkan karena tingkat pendidikan dan sosial ekonomi kurang serta akibat kebiasaan atau budaya masyarakat yang salah. Penyakit diare yang terjadi pada bayi atau anak ditandai dengan buang air besar dengan frekuensi 3 kali atau lebih per hari, disertai perubahan tinja menjadi cair, dengan atau tanpa lendir dan darah (Maryunani, 2010).

Diare merupakan penyebab utama morbiditas dan merupakan penyakit yang umum terjadi pada anak di berbagai negara. Di negara berkembang, diare merupakan penyebab utama kematian pada anak. Epidemiologi gastroenteritis bergantung pada faktor penyebabnya. Cara penyebaran penyakit adalah dengan kontak erat dari orang ke orang, melalui makanan atau minuman yang terkontaminasi, serta dari binatang ke manusia. Seringkali kuman menyebar melalui berbagai rute (Marcdante et al., 2018).

Diare mempunyai dampak negatif terhadap status gizi penderita karena berkurangnya asupan makanan, hal ini disebabkan karena terjadinya anoreksia (sebagai gejala penyakit) atau dihentikannya beberapa macam makanan oleh orang tua karena ketidaktahuan, disamping itu muntah juga merupakan salah satu penyebab dari berkurangnya intake makanan. Penderita diare juga mengalami malabsorpsi dari nutrien makro maupun mikro, peningkatan kebutuhan energi dan disertai kehilangan nitrogen dan elektrolit intrasel melalui ekskresi urine, peluh dan tinja hingga akhirnya menyebabkan penurunan status gizi penderita (Sinthamurniwaty, 2006). Asupan energi yang tidak adekuat, penyakit non infeksi, diet khusus dan lama hari perawatan merupakan faktor yang mempengaruhi terjadinya malnutrisi di rumah sakit (Kemenkes RI, 2014).

Parameter status gizi yang sering digunakan adalah berat badan. Berat badan merupakan parameter antropometri pilihan utama karena beberapa alasan, yaitu untuk melihat perubahan dalam waktu singkat, memberikan gambaran status gizi sekarang, dan parameter yang sudah umum digunakan. Penentuan dilakukan dengan cara menimbang (Supariasa dan Hardinsyah, 2017).

Menurut Emiralda (2007), anak usia bawah lima tahun (balita) lebih rentan menderita penyakit infeksi karena sudah mulai bergerak aktif untuk bermain, sehingga lebih mudah terkontaminasi oleh kotoran. Anak usia 2-5 tahun sudah mulai memiliki kebiasaan membeli makanan jajanan yang belum tentu terjaga kebersihannya, baik dalam pengolahan 
maupun penyajiannya, sehingga sangat mudah terkontaminasi oleh kuman yang bisa menyebabkan diare.

Tingkat derajat penyakit merupakan prediktor yang signifikan untuk terjadinya kehilangan berat badan $>2 \%$ selama perawatan serta berhubungan dengan terjadinya hospital malnutrition, dan akhirnya dapat memperpanjang lama perawatan (Kasim et al., 2016).

Hasil penelitian yang dilakukan oleh Sahalessy, et al (2014) tentang hubungan antara asupan energi dengan status gizi batita umur 1-3 tahun di desa Mopusi Kecamatan Bolaang Mongondow Induk Sulawesi Utara, didapatkan hasil ada hubungan bermakna antara asupan energi dengan status gizi berdasarkan indeks BB/U. Penelitian lain yang dilakukan oleh Umah dan Bambang di RSUD Dr. Moh. Soewandhie Surabaya (2014) tentang asupan protein, lemak, karbohidrat dan lama hari rawat inap pada pasien demam tifoid didapatkan bahwa ada hubungan antara asupan energi, protein dan karbohidrat dengan lama hari rawat.

Period prevalence diare pada Riset Kesehatan Dasar (Riskesdas) tahun 2013 $(3,5 \%)$ lebih kecil dari Riskesdas tahun 2007 (9,0\%). Penurunan period prevalence yang tinggi ini dimungkinkan karena waktu pengambilan sampel yang tidak sama antara tahun 2007 dan tahun 2013. Pada Riskesdas tahun 2013 sampel diambil dalam rentang waktu yang lebih singkat. Insiden diare untuk seluruh kelompok umur di Indonesia adalah 3.5\%. Lima provinsi dengan insiden dan period prevalence diare tertinggi adalah Papua (6,3\% dan 14,7\%), Sulawesi Selatan (5,2\% dan 10,2\%), Aceh (5,0\% dan 9,3\%), Sulawesi Barat $(4,7 \%$ dan $10,1 \%)$, dan Sulawesi Tengah (4,4\% dan 8,8\%). Insiden dan period prevalence diare yang terjadidi Provinsi Kalimantan Tengah berada pada urutan 22 yaitu 2,6\% dan 5,4\% (Riskesdas, 2013).

Berdasarkan karakteristik penduduk, kelompok umur balita adalah kelompok yang paling tinggi menderita diare. Insiden diare balita di Indonesia adalah 6,7\%. Lima provinsi dengan insiden diare tertinggi adalah Aceh (10,2\%), Papua $(9,6 \%)$, DKI Jakarta (8,9\%), Sulawesi Selatan $(8,1 \%)$, dan Banten $(8,0 \%)$. Karakteristik diare balita tertinggi terjadi pada kelompok umur 12-23 bulan (7,6\%), laki-laki (5,5\%), dan kelompok yang tinggal di daerah pedesaan $(5,3 \%)$ (Riskesdas, 2013).

Diare merupakan 10 penyakit terbanyak di RSUD dr. Doris Sylvanus Palangka Raya. Jumlah pasien anak yang didiagnosa menderita diare (gastroenteritis acute) yang dirawat inap di ruang Flamboyant (anak) RSUD dr. Doris Sylvanus Palangka Raya pada Januari 
sampai dengan Desember tahun 2017 yaitu sebanyak 406 kasus, dengan kelompok umur 28 hari-1 tahun (33\%), 1-4 tahun (49\%), dan usia 5-14 tahun (18\%) (Register Ruang F RSUD dr. Doris Sylvanus, 2017).

Penelitian ini bertujuan untuk mengetahui hubungan asupan energi, cairan dan lama hari rawat inap dengan perubahan berat badan pada pasien balita diare selama dirawat di RSUD dr. Doris Sylvanus Palangka Raya. Hasil penelitian ini harapannya dapat dijadikan dasar untuk lebih memperhatikan pemenuhan nutrisi dan cairan pada pasien diare.

\section{METODE}

Rancangan penelitian menggunakan rancangan cross sectional yang bersifat deskriptif analitik. Penelitian dilakukan pada pasien balita yang menderita diare di RSUD dr. Doris Sylvanus Palangka Raya pada bulan Januari - April 2019.

Jumlah sampel diperoleh berjumlah 30 orang, yang diambil dengan teknik purposive sampling. Data primer yang dikumpulkan yaitu karakteristik sampel yang meliputi umur dan jenis kelamin yang diperoleh dengan cara wawancara. Data BB (awal dan akhir perawatan) sampel diperoleh melalui penimbangan $\mathrm{BB}$ menggunakan timbangan digital dengan tingkat ketelitian 0,1 kg. Data asupan energi dan cairan diperoleh dengan food recall 24 jam selama pasien dirawat. Data bentuk makanan, jenis nutrisi parenteral dan lama hari rawat inap diperoleh melalui observasi.

Data asupan yang terkumpul diolah dengan komputer menggunakan program nutrisurvey. Analisis data dilakukan secara univariat dan bivariat. Analisis bivariat dengan menggunakan uji uji regresi linear sederhana dan uji spearman melalui program SPSS versi 20 untuk mengetahui hubungan asupan energi, cairan dan lama hari rawat inap dengan perubahan berat badan pada pasien balita diare selama dirawat.

\section{HASIL DAN PEMBAHASAN}

Umur adalah lama hidup seseorang yang dihitung berdasarkan tahun penuh. Distribusi frekuensi umur sampel dapat dilihat pada tabel 1 .

Tabel 1. Distribusi Frekuensi Sampel Berdasarkan Umur

\begin{tabular}{ccc}
\hline $\begin{array}{c}\text { Usia } \\
\text { (tahun) }\end{array}$ & Jumlah & Persentase (\%) \\
\hline $\mathbf{2}$ & 11 & 36,7 \\
$\mathbf{3}$ & 6 & 20,0 \\
$\mathbf{4}$ & 5 & 16,7 \\
$\mathbf{5}$ & 8 & 26,7 \\
\hline Total & $\mathbf{3 0}$ & $\mathbf{1 0 0}$ \\
\hline
\end{tabular}

Distribusi frekuensi berdasarkan Tabel 1. Menunjukan sampel terbanyak adalah dengan usia 2 tahun yaitu 11 orang $(36,7 \%)$ dan paling sedikit berumur 4 tahun sebanyak 5 orang $(16,7 \%)$.

Distribusi frekuensi berdasarkan jenis kelamin sampel dapat dilihat pada tabel 2 . 
Tabel 2. Distribusi Frekuensi Sampel Berdasarkan Jenis Kelamin

\begin{tabular}{ccc}
\hline Jenis Kelamin & Jumlah & Persentase \\
\hline Laki-laki & 15 & 50 \\
Perempuan & 15 & 50 \\
\hline Total & $\mathbf{3 0}$ & $\mathbf{1 0 0}$ \\
\hline
\end{tabular}

Distribusi frekuensi berdasarkan

Tabel 2. Menunjukan bahwa sampel dengan jenis kelamin laki-laki dan perempuan berjumlah sama yaitu masing-masing 15 orang $(50 \%)$.

Distribusi frekuensi berdasarkan bentuk makanan yang diperoleh selama pasien dirawat dapat dilihat pada tabel 3 .

Tabel 3. Distribusi Frekuensi Sampel Berdasarkan Bentuk Makanan

\begin{tabular}{|c|c|c|}
\hline $\begin{array}{c}\text { Bentuk } \\
\text { Makanan }\end{array}$ & Jumlah & Persentase \\
\hline Bubur & 4 & 13,3 \\
\hline Nasi Lunak & 26 & 86,7 \\
\hline Total & 30 & 100 \\
\hline
\end{tabular}

Berdasarkan tabel 3. dapat diketahui bahwa bentuk makanan terbanyak dalam penelitian ini adalah nasi lunak yaitu 26 orang $(86,7 \%)$.

Distribusi frekuensi berdasarkan jenis nutrisi parenteral sampel dapat dilihat pada tabel 4.

Tabel 4. Distribusi Frekuensi Sampel Berdasarkan Jenis Nutrisi Parenteral

\begin{tabular}{ccc}
\hline Jenis Parenteral & Jumlah & Persentase \\
\hline KA-EN 3B & 20 & 66,7 \\
KA-EN 4B & 10 & 33,3 \\
\hline Total & $\mathbf{3 0}$ & $\mathbf{1 0 0}$ \\
\hline
\end{tabular}

Berdasarkan tabel 4. dapat diketahui bahwa jenis nutrisi parenteral yang paling banyak digunakan pada sampel adalah KAEN 3B yaitu sebanyak 20 orang $(66,7 \%)$.
Distribusi frekuensi berdasarkan asupan energi sampel dapat dilihat pada tabel 5 .

Tabel 5. Distribusi Frekuensi Sampel Berdasarkan Asupan Energi

\begin{tabular}{ccc}
\hline $\begin{array}{c}\text { Berdasarkan Asupan Energi } \\
\text { Energi }\end{array}$ & Jumlah & $\%$ \\
\hline Di atas Kebutuhan & 1 & 3,3 \\
Normal & 2 & 6,7 \\
Defisit Ringan & 7 & 23,3 \\
Defisit Sedang & 8 & 26,7 \\
Defisit Berat & 12 & 40,0 \\
\hline Total & $\mathbf{3 0}$ & $\mathbf{1 0 0}$ \\
\hline
\end{tabular}

Berdasarkan tabel 5. diketahui bahwa asupan energi rata-rata sampel sebanyak 12 orang (40\%) sampel termasuk dalam kategori defisit berat, 8 orang $(26,7 \%)$ kategori defisit sedang, 7 orang $(23,3 \%)$ defisit ringan, 2 orang $(6,7 \%)$ normal dan 1 orang $(3,3 \%)$ kelebihan asupan energi. Jumlah asupan rata-rata sampel yaitu berkisar antara 590,3 kalori hingga 1493,8 kalori, rata-rata asupan terbanyak diperoleh dari asupan oral yaitu $89,6 \%$ sedangkan asupan parenteral yaitu $10,4 \%$.

Distribusi frekuensi berdasarkan asupan cairan sampel dapat dilihat pada tabel 6 .

\begin{tabular}{ccc}
\multicolumn{3}{c}{$\begin{array}{l}\text { Tabel 6. Distribusi Frekuensi Sampel } \\
\text { Berdasarkan Asupan Cairan }\end{array}$} \\
\hline $\begin{array}{c}\text { Kategori Asupan } \\
\text { Cairan }\end{array}$ & Jumlah & $\%$ \\
\hline Di atas Kebutuhan & 25 & 83,3 \\
Normal & 5 & 16,7 \\
\hline Total & $\mathbf{3 0}$ & $\mathbf{1 0 0}$ \\
\hline
\end{tabular}

Berdasarkan tabel 6. dapat diketahui bahwa asupan cairan rata-rata sampel sebanyak 25 orang $(83,3 \%)$ sampel memiliki kategori asupan cairan di atas 
kebutuhan dan 5 orang $(16,7 \%)$ termasuk kategori normal. Jumlah asupan cairan ratarata sampel yaitu berkisar antara 1212,2 ml hingga 2298,5 ml, rata-rata asupan cairan terbanyak diperoleh dari asupan parenteral yaitu 55,7\% sedangkan asupan oral 44,3\%.

Distribusi frekuensi berdasarkan lama hari rawat inap sampel dapat dilihat pada tabel 7.

\begin{tabular}{ccc}
\multicolumn{3}{c}{ Tabel 7. Distribusi Frekuensi Sampel } \\
\multicolumn{3}{c}{ Berdasarkan Lama Hari Rawat Inap } \\
\hline $\begin{array}{c}\text { Lama hari } \\
\text { rawat inap }\end{array}$ & Jumlah & $\%$ \\
\hline < 5 hari & 22 & 73,3 \\
$\geq \mathbf{5}$ hari & 8 & 26,7 \\
\hline Total & $\mathbf{3 0}$ & $\mathbf{1 0 0}$ \\
\hline
\end{tabular}

Berdasarkan tabel 7. Dapat diketahui bahwa jumlah pasien dengan lama hari rawat inap terbanyak yaitu $<5$ hari sebanyak 22 orang $(73,3 \%)$ sedangkan yang terendah yaitu dengan lama hari rawat inap $\geq 5$ hari sebanyak 8 orang $(26,7 \%)$. Dalam penelitian ini didapat rata-rata hari rawat inap adalah 3,5 hari

Distribusi frekuensi berdasarkan perubahan berat badan sampel dapat dilihat pada tabel 8.

\begin{tabular}{ccc}
\multicolumn{3}{c}{ Tabel 8. Distribusi Frekuensi Sampel } \\
\multicolumn{3}{c}{ Berdasarkan Perubahan Berat Badan } \\
\hline $\begin{array}{l}\text { Lama hari } \\
\text { rawat inap }\end{array}$ & Jumlah & $\%$ \\
\hline Turun & 8 & 26,7 \\
Tetap & 1 & 3,3 \\
Naik & 21 & 70 \\
\hline Total & $\mathbf{3 0}$ & $\mathbf{1 0 0}$ \\
\hline
\end{tabular}

Berdasarkan tabel 4.8 diketahui bahwa sampel yang mengalami penurunan berat badan sebanyak 8 orang $(26,7 \%)$, tidak terjadi perubahan berat badan atau tetap sebanyak 1 orang $(3,3 \%)$ dan terjadi kenaikan berat badan sebanyak 21 orang $(70 \%)$.

Karakteristik sampel yang tersaji pada tabel 1. menunjukkan usia sampel terbanyak pada usia 2 tahun. Menurut Emiralda (2007), anak usia bawah lima tahun (balita) lebih rentan menderita penyakit infeksi karena sudah mulai bergerak aktif untuk bermain, sehingga lebih mudah terkontaminasi oleh kotoran. Anak usia 2-5 tahun sudah mulai memiliki kebiasaan membeli makanan jajanan yang belum tentu terjaga kebersihannya, baik dalam pengolahan maupun penyajiannya, sehingga sangat mudah terkontaminasi oleh kuman yang bisa menyebabkan diare.

Karakteristik sampel berdasarkan jenis kelamin yang tersaji pada tabel 2 . menunjukkan jumlah yang sama antara laki-laki dan perempuan. Berdasarkan hasil Riskesdas 2013, karakteristik diare balita tertinggi terjadi pada kelompok jenis kelamin laki-laki, berbeda dengan hasil penelitian Yusuf (2011) yaitu jenis kelamin tidak memberikan perbandingan yang jauh berbeda sehingga pada kasus diare jenis kelamin tidak mempengaruhi kejadian diare. Sejalan dengan penelitian ini yang 
menunjukkan bahwa penyakit diare merupakan penyakit yang tidak dipengaruhi oleh jenis kelamin.

Bentuk makanan yang diperoleh sampel selama perawatan tersaji pada tabel 3. menunjukkan bentuk makanan terbanyak adalah nasi lunak. Makanan lunak adalah makanan yang memiliki tekstur yang mudah dikunyah, ditelan, dan dicerna dibandingkan makanan biasa. Makanan ini mengandung cukup zat gizi, asalkan pasien mampu mengkonsumsi makanan dalam jumlah cukup. Menurut keadaan penyakit, makanan lunak dapat diberikan langsung kepada pasien atau sebagai perpindahan dari makanan saring ke makanan biasa (Almatsier, 2006).

Jenis nutrisi parenteral paling banyak digunakan sampel adalah KA-EN 3B seperti yang tersaji pada tabel 4. KA-EN 3B diberikan untuk memenuhi kebutuhan harian air dan elektrolit dengan kandungan kalium cukup untuk mengganti ekskresi harian, pada asupan oral terbatas (Otsuka, 2003). Pemberian cairan parenteral pada penelitian ini sesuai dengan pedoman penanganan anak diare dimana rentan mengalami dehidrasi. Semua anak dengan diare, harus diperiksa apakah menderita dehidrasi dan klasifikasikan status dehidrasi sebagai dehidrasi berat, dehidrasi ringan/sedang atau tanpa dehidrasi dan beri pengobatan yang sesuai. Meskipun belum terjadi dehidrasi berat tetapi bila anak sama sekali tidak bisa minum oralit misalnya karena anak muntah profus, dapat diberikan infus dengan cara beri cairan intravena secepatnya (WHO, 2009).

Asupan energi rata-rata sampel terbanyak termasuk dalam kategori defisit berat seperti yang tersaji pada tabel 5. yang bersumber dari asupan oral yaitu $89,6 \%$ sedangkan asupan parenteral yaitu 10,4\% Menurut Umah dan Bambang (2014), asupan energi berhubungan dengan lama hari rawat inap. Perlu adanya peningkatan asupan nutrisi berupa energi, protein dan karbohidrat pada pasien dengan demam tifoid untuk mempercepat proses penyembuhan sehingga mempersingkat lama hari rawat. Gizi parenteral dapat mengandung protein, karbohidrat, lipid, vitamin, mineral, dan elektrolit dalam jumlah yang disesuaikan dengan kebutuhan pasien perorangan. Gizi parenteral biasanya diberikan bagi pasien yang mengalami sindrom usus pendek, sumbatan usus, diare berat, atau perdarahan berat gastrointestinal. Fungsi utama karbohidrat parenteral adalah sebagai sumber energi. Karbohidrat optimal adalah jumlah yang dibutuhkan untuk mengganti protein tanpa menyebabkan hiperglikemia. Karbohidrat komersial terdiri dari monohidrat dekstrosa anhydrous dalam air steril. Larutan tersebut tersedia dalam konsentrasi dengan kisaran 
antara 5-70\% dan mengandung 3,4 kalori per gram dekstrosa (Skipper, 2019).

Asupan cairan rata-rata sampel terbanyak termasuk dalam kategori asupan di atas kebutuhan seperti yang tersaji pada tabel 6. yang bersumber dari asupan parenteral yaitu 55,7\% sedangkan asupan oral 44,3\%. Dukungan nutrisi secara parenteral dapat didefinisikan sebagai pemberian asupan nutrisi yang diberikan melalui pembuluh darah dan masuk dalam sirkulasi darah. Cairan yang diberikan pada pemberian nutrisi parenteral ditentukan oleh status hidrasi, usia penderita, faktor lingkungan, dan penyakit yang mendasari. Pemberian cairan tidak boleh diberikan secara berlebihan, untuk mencegah terjadinya overload cairan (Gurnida, 2010). Asupan cairan sangat penting pada anak diare karena anak diare berisiko mengalami dehidrasi. Penghitungan asupan cairan meliputi asupan minum per oral, makanan, makanan cair, cairan parenteral, obatobatan intavena, serta irigasi kateter atau slang (Tamsuri, 2009).

Lama hari rawat inap sampel terbanyak yaitu $<5$ hari seperti yang tersaji pada tabel 7. dengan rata-rata hari rawat inap adalah 3,5 hari. Yusuf (2011) menyatakan lama hari rawat digolongkan menjadi, hari rawat kurang dari 5 hari dan lebih/sama dengan 5 hari. Batasan tersebut ditentukan atas dasar rata-rata lama hari rawat inap yang dihubungkan dengan batasan jangka waktu diare akut yaitu kurang dari 7 hari. Diare melanjut yaitu diare yang berlangsung antara 7-14 hari, sedangkan bila lebih dari 14 hari disebut diare persisten. Penyakit penyerta adalah penyakit lain yang dialami oleh pasien saat masuk perawatan di rumah sakit. Berdasarkan lama rawatan dari 104 pasien diare sebagian besar didapatkan kurang dari 5 hari yaitu $94(90,4 \%)$ pasien. Menurut Depkes RI (2005) lama hari rawat merupakan salah satu unsur atau aspek asuhan pelayanan di rumah sakit yang dapat dinilai dan diukur. Lama hari rawat yang memanjang dapat disebabkan oleh kondisi medis pasien atau adanya infeksi nosokomial yang memperpanjang lama hari rawat-nya bisa mencapai 5-20 hari. Richard Johnson dan Jennifer Simpson (2009) menyebutkan bahwa lama hari rawat dapat bertambah karena adanya infeksi nosokomial menjadi 13,3 hari, lebih lama 2 kali lipat dibandingkan daripada normalnya. Selain karena kondisi medis, lama hari rawat juga dapat disebabkan oleh kondisi non-medis, seperti kelambatan administrasi (administration delay) di rumah sakit, kurang baiknya perencanaan dalam memberikan pelayanan kepada pasien (patient scheduling) atau kebijakan di bidang medis (medical policy) (Wartawan, 2012). 
Perubahan berat badan pada sampel selama perawatan terbanyak yaitu terjadi kenaikan berat badan seperti yang tersaji pada tabel 8. Berat badan menggambarkan jumlah protein, lemak, air, dan mineral yang terdapat di dalam tubuh. Ada beberapa alasan mengapa berat badan digunakan sebagai parameter antropometri. Alasan tersebut diantaranya adalah perubahan berat badan mudah terlihat dalam waktu singkat dan berat badan dapat menggambarkan status gizi saat ini. Pengukuran berat badan mudah dilakukan dan alat ukur untuk menimbang berat badan mudah diperoleh (Par'i, 2016). Menurut Rodriguez dan Ortiz (2011) diare juga merupakan salah satu penyakit infeksi yang berperan dalam kejadian malnutrisi. Diare disertai dengan gejala mual dan muntah dapat meningkatkan kehilangan cairan tubuh yang berdampak pada dehidrasi dan penurunan berat badan seseorang. Hal tersebut apabila berlangsung dalam jangka waktu yang panjang dapat memperparah kondisi gizi kurang dan meningkatkan terjadinya kondisi gizi buruk balita. Selain itu menurut Basari (2009) diare menyebabkan penurunan nafsu makan sehingga asupan zat gizi rendah yang mengakibatkan pada penyerapan dan pemanfaatan zat gizi seperti energi, karbohidrat, lemak dan protein berjalan tidak optimal.
Berdasarkan hasil uji normalitas didapatkan hasil asupan energi $(\mathrm{p}=0,2)$ asupan cairan $(\mathrm{p}=0,049)$ dan lama hari rawat inap $(\mathrm{p}=0,005)$.

1. Hubungan Asupan Energi dengan Perubahan Berat Badan

Berdasarkan hasil uji statistik diperoleh nilai Sig. 0,5 menunjukkan bahwa tidak ada hubungan asupan energi terhadap perubahan berat badan pasien anak diare. Diare mempunyai dampak negatif terhadap status gizi penderita karena berkurangnya asupan makanan, hal ini disebabkan karena terjadinya anoreksia (sebagai gejala penyakit) atau dihentikannya beberapa macam makanan oleh orang tua karena ketidaktahuan, disamping itu muntah juga merupakan salah satu penyebab dari berkurangnya intake makanan. Penderita diare juga mengalami malabsorpsi dari nutrien makro maupun mikro, peningkatan kebutuhan energi dan disertai kehilangan nitrogen dan elektrolit intrasel melalui ekskresi urine, peluh dan tinja hingga akhirnya menyebabkan penurunan status gizi penderita (Sinthamurniwaty, 2006).

Penelitian yang dilakukan oleh Scrimshaw (2003) memperlihatkan bahwa terdapat hubungan timbal balik antara diare dan malnutrisi. Diare dapat menimbulkan terjadinya malnutrisi dan sebaliknya, malnutrisi juga bisa menjadi penyebab timbulnya diare. Infeksi mempengaruhi 
status gizi melalui penurunan asupan makanan, penurunan absorpsi makanan di usus, meningkatkan katabolisme, dan mengambil nutrisi yang diperlukan tubuh untuk sintesis jaringan dan pertumbuhan. Di samping itu, malnutrisi bisa menjadi faktor predisposisi terjadinya infeksi karena menurunkan pertahanan tubuh dan mengganggu fungsi kekebalan tubuh manusia. Penelitian yang dilakukan oleh Sahalessy (2014) menyatakan terdapat hubungan bermakna antara asupan energi dengan status gizi $(\mathrm{BB} / \mathrm{U})$.

2. Hubungan Asupan Cairan dengan Perubahan Berat Badan

Berdasarkan hasil uji statistik diperoleh nilai Sig. 0,049 yang menunjukkan ada hubungan yang signifikan antara asupan cairan terhadap perubahan berat badan pasien anak diare. Air adalah komponen utama dalam tubuh manusia. Persentase cairan tubuh total (CTT) atau total body water terhadap berat badan bervariasi menurut usia. Janin memiliki CTT yang tinggi dan menurun secara gradual menjadi sekitar $75 \%$ berat badan, saat bayi lahir cukup bulan. CTT akan menurun secara bertahap hingga mencapai $60 \%$ berat badan pada akhir tahun pertama kehidupan. Proporsi CTT terhadap berat badan ini akan menetap hingga awal masa pubertas (Marcdante et al., 2018).
Air berperan penting dalam kehidupan, bahkan semua sistem organ bergantung padanya seperti darah, enzim, hormon, cairan plasma serta cairan sel. Selain itu air mempunyai peran dalam proses pelarutan, pencernaan, penyerapan zat gizi, pembuangan sisa serta pengaturan keseimbangan mineral, elektrolit, asam basa dan suhu tubuh. Air dibutuhkan tubuh dalam jumlah yang paling banyak dibandingkan kebutuhan zat gizi lainnya, sehingga air dikategorikan sebagai zat gizi makro bersama karbohidrat, lemak, dan protein. Apabila tubuh kekurangan cairan, agar tetap dapat menyeimbangkan kadar air, maka tubuh secara otomatis akan mencari jalan mengambil sumber air (Indar, 2010). Hal ini menjadi salah satu penyebab mengapa asupan cairan berhubungan dengan terjadinya perubahan berat badan.

Penelitian yang dilakukan oleh Buanasita et al., (2014) tentang perbedaan tingkat konsumsi energi, lemak, cairan, dan status hidrasi mahasiswa obesitas dan non obesitas. Dehidrasi merupakan kondisi kekurangan cairan tubuh karena jumlah cairan yang keluar lebih banyak daripada jumlah cairan yang masuk. Terdapat 37,3\% remaja asupan cairannya kurang dari $90 \%$ kebutuhannya atau risiko dehidrasi. Dehidrasi dapat menjadi faktor risiko terjadinya obesitas pada anak dan remaja di 
samping asupan energi dan lemak yang berlebihan.

3. Hubungan Lama Hari Rawat Inap dengan Perubahan Berat Badan

Berdasarkan hasil uji statistik diperoleh nilai Sig. 0,820 yang menunjukkan tidak ada hubungan yang signifikan antara lama hari rawat inap terhadap perubahan berat badan pasien anak diare. Hal ini berbeda dengan penelitian yang dilakukan oleh Poerwati (2012) yang menyatakan berat badan dan tinggi badan mempunyai pengaruh terhadap lama perawatan. Menurut Depkes RI (2005) lama hari rawat merupakan salah satu unsur atau aspek asuhan pelayanan di rumah sakit yang dapat dinilai dan diukur. Lama hari rawat yang memanjang dapat disebabkan oleh kondisi medis pasien atau adanya infeksi nosokomial yang memperpanjang lama hari rawat-nya bisa mencapai 5-20 hari. Richard Johnson dan Jennifer Simpson (2009) menyebutkan bahwa lama hari rawat dapat bertambah karena adanya infeksi nosokomial menjadi 13,3 hari, lebih lama 2 kali lipat dibandingkan daripada normalnya. Selain karena kondisi medis, lama hari rawat juga dapat disebabkan oleh kondisi non-medis, seperti kelambatan administrasi (administration delay) di rumah sakit, kurang baiknya perencanaan dalam memberikan pelayanan kepada pasien (patient scheduling) atau kebijakan di bidang medis (medical policy) (Wartawan, 2012).

\section{KESIMPULAN}

Tidak ada hubungan asupan energi terhadap perubahan berat badan, tidak ada hubungan antara lama hari rawat inap terhadap perubahan berat badan pada pasien anak diare pasien anak diare, dan ada hubungan yang signifikan antara asupan cairan terhadap perubahan berat badan pasien anak diare.

\section{DAFTAR PUSTAKA}

Almatsier S. 2006. Penuntun Diet Edisi Baru. PT Gramedia Pustaka Utama. Jakarta.

Basari M. 2007. Nutrition At A Glance. Penerjemah : Hermin 2009 At A Glance : Ilmu Gizi. Erlangga. Jakarta.

Buanasita A, Andriyanto, dan Indah S. 2015. Perbedaan Tingkat Konsumsi Energi, Lemak, Cairan, dan Status Hidrasi Mahasiswa Obesitas dan Non Obesitas. Indonesian Journal of Human Nutrition, Juni 2015, Vol.2 No.1 : 11 22.

http://ijhn.ub.ac.id/index.php/ijhn/article/view/ 114 [Diakses tanggal 26 Desember 2018]

Departemen Kesehatan RI. 2005. Standar Pelayanan Minimal, Direktorat Jenderal Bina Kesehatan Masyarakat. Jakarta.

Dinniyyah SR dan Triska SN. 2017. Asupan Energi, Protein dan Lemak dengan Kejadian Gizi Kurang pada Balita Usia 24-59 Bulan di Desa Suci, Gresik. Amerta Nutr (2017) 341-350. https://ejournal.unair.ac.id/AMNT/article/download/7 139/4390 [Diakses tanggal 13 Juni 2019]

Emiralda. 2007. Pengaruh Pola Asuh Anak Terhadap Terjadinya Balita Malnutrisi di Wilayah Kerja Puskesmas Montasik Kecamatan Montasik Kabupaten Aceh Besar Tahun 2006 (tesis). Medan : Universitas Sumatera Utara.

Gurnida DA. 2010. Pemberian Dukungan Gizi Pada Anak Sakit : Enteral dan Parenteral. http://pustaka.unpad.ac.id/wp- 
content/uploads/2013/12/Pustaka Unpad Pemberian Dukungan_Gizi - pada Anak-Sakit.pdf [Diakses tanggal 13 Juni 2019]

Kasim DA, Vera, dan Olga. 2016. Asupan Makanan, Status Gizi dan Lama Hari Rawat Inap pada Pasien Penyakit Dalam di Rumah Sakit Advent Manado. GIZIDO 8(2). https://docplayer.info/30207462-Asupanmakanan-status-gizi-dan-lama-hari-rawatinap-pada-pasien-penyakit-dalam-di-rumahsakit-advent-manado.html [Diakses tanggal 6 Desember 2018]

Kemenkes RI. 2014. Peraturan Menteri Kesehatan Republik Indonesia Nomor 78 Tahun 2013 tentang Pedoman Pelayanan Gizi Rumah Sakit. Kemenkes RI. Jakarta.

Kemenkes RI. 2014. Standar Pemantauan Pertumbuhan Balita. Direktorat Bina Gizi. Jakarta.

Marcdante KJ, Robert, Hal, dan Richard. 2018. Nelson Ilmu Kesehatan Anak esensial edisi Update Keenam. Ikatan Dokter Anak Indonesia. Indonesia.

Maryunani A. 2010. Ilmu Kesehatan Anak. CV. Trans Info Media. Jakarta.

Otsuka. 2003. Pedoman Cairan Infus Edisi Revisi III. PT Otsuka Indonesia.

Par'i HM. 2016. Penilaian Status Gizi. Penerbit Buku Kedokteran EGC. Jakarta.

Poerwati E. 2013. Determinan Lama Rawat Inap Pasien Balita dengan Diare. Jurnal Kedokteran Brawijaya, $27 \quad$ (4). https://jkb.ub.ac.id/index.php/jkb/article/view/ 380 [Diakses tanggal 12 Desember 2018]

Richard Johnson, Jennifer Simpson. 2009. Reducing Length of Stay for Colorectal Surgery Patients using Enhanced Recovery Techniques. Cancer Inpatient Case Study. NHS Improvement.

Rodriguez, L.C.E., Ortiz, R. 2011. Malnutrition and Gastroinstestinal and Respiratory Infections in Children: A Public Health Problem, International Journal of Environmental Research and Public Health. 8:1174 - 205. https://www.ncbi.nlm.nih.gov/pmc/articles/P MC3118884/

Rosari A, Eka, dan Masrul. 2013. Hubungan Diare dengan Status Gizi Balita di Kelurahan Lubuk Buaya Kecamatan Koto Tangah Kota Padang. Jurnal Kesehatan Andalas. http://Jurnal.fk.unand.ac.id. [Diakses tanggal 6 Desember 2018]

Sahalessy RKF, Nova, dan Nelly. 2015. Hubungan antara Asupan Energi dengan Status Gizi Batita umur 1-3 Tahun di Desa Mopusi Kecamatan Bolang Mongondow Induk Sulawesi Utara tahun 2014. Jurnal e-Biomedik (eBm). https://media.neliti.com/media/publications/68 155-ID-hubungan-antara-asupan-energi- dengan-sta.pdf. [Diakses tanggal 6 Desember 2018]

Scrimshaw NS. 2003. Historical Concepts of Interactions, Synergism and Antagonism Between Nutrition and Infection. $J$. Nutr.133:316S-21S.

Sinthamurniwaty. 2006. Faktor-Faktor Resiko Kejadian Diare Akut Pada Balita. Tesis. Universitas Diponegoro, Semarang. http://eprints.undip.ac.id/15323/1/SINTAMU RNIWATYE4D002073.pdf. [Diakses tanggal 13 Oktober 2018]

Skipper A. 2019. Gizi Enteral dan Parenteral. Penerbit Buku Kedokteran EGC. Jakarta.

Supariasa IDN dan Hardinsyah. 2017. Ilmu Gizi Teori \& Aplikasi. Penerbit Buku Kedokteran EGC. Jakarta.

Tamsuri A. 2009. Seri Asuhan Keperawatan: Klien Gangguan Keseimbangan Cairan dan Elektrolit. EGC. Jakarta

Umah AK dan Bambang W. 2014. Asupan Protein, Lemak, Karbohidrat Dan Lama Hari Rawat Pasien Demam Tifoid di RSUD Dr. Moh. Soewandhie Surabaya. Jurnal Widya Medika Surabaya 2(2). http://jurnal.wima.ac.id/index.php/JWM/articl e/view/850 [Diakses tanggal 6 Desember 2018]

Wartawan IW. 2012. Analisis lama Hari Rawat Pasien Yang menjalani Pembedahan di Ruang Rawat Inap Bedah kelas III RSUP Sanglah Denpasar Tahun 2011, Tesis. http://lib.ui.ac.id/file?file=digital/20308126T\%2031679-Analisis\%20lamafull\%20text.pdf [Diakses tanggal 12 Desember 2018]

WHO. 2009. Buku Saku Pelayanan Kesehatan Anak Di Rumah Sakit. http://www.searo.who.int/indonesia/document s/9789791947701-buku-saku-kesehatan-anakindonesia.pdf [Diakses tanggal 14 Desember 2018]

Yusuf S. 2011. Profil Diare di Ruang Rawat Inap Anak. Sari Pediatri 3(4) https://saripediatri.org/index.php/saripediatri/article/download/424/356. [Diakses tanggal 28 Mei 2019] 